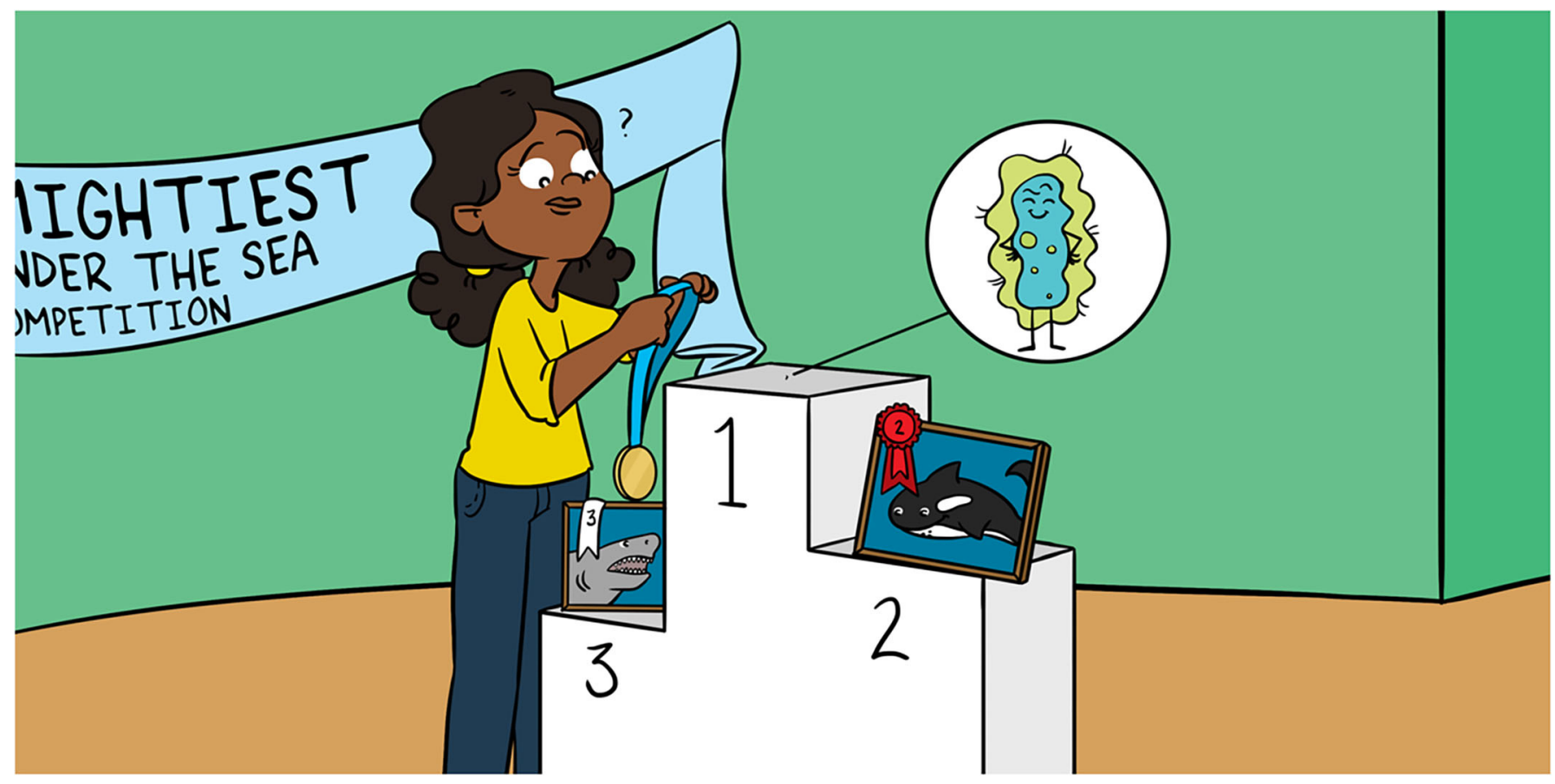

\title{
TINY PHYTOPLANKTON: THE MOST POWERFUL ORGANISMS OF THE OCEANS!
}

\section{Patricia M. Glibert *}

Horn Point Laboratory, University of Maryland Center for Environmental Science, Cambridge, MD, United States

\section{YOUNG REVIEWER:}

ARIA

AGE: 9
Although sharks, whales, and other large organisms come to mind when one thinks about the most important or most powerful organisms of the sea, in fact, the most powerful are the tiny phytoplankton. Phytoplankton, which are microscopic algae, hold this power because they harvest the light from the sun, making food for all other organisms. Phytoplankton are the foundation for the ocean ecosystem. Through the process of photosynthesis, they also make oxygen and are responsible for almost half of the oxygen in the world. However, some phytoplankton can also be harmful and can kill fish or damage ecosystems. These harmful phytoplankton can also make people sick. The phytoplankton are tiny but mighty!

\section{WHAT ARE THE MOST POWERFUL ORGANISMS OF THE OCEAN?}

When you think of the most powerful organisms in the sea, does a shark come to mind? Or maybe a huge killer whale? Other powerhouses of the ocean include the sailfish that use their jaws like 
Figure 1

Every drop of seawater has thousands of microscopic plankton. A great diversity of phytoplankton is seen if one compares samples from different areas or different times. (Image credits: the symbol library of the University of Maryland Integration and Application Network.)

\section{PLANKTON}

Microscopic organisms in the sea or in freshwater.

\section{PHYTOPLANKTON}

Plant-like plankton that perform

photosynthesis, turning light from the sun, along with $\mathrm{CO}_{2}$ from the water, into oxygen and the energy needed to grow.

\section{PHOTOSYNTHESIS}

The process by which green plants and plant-like algae use sunlight, together with carbon dioxide and water, to make their own food.

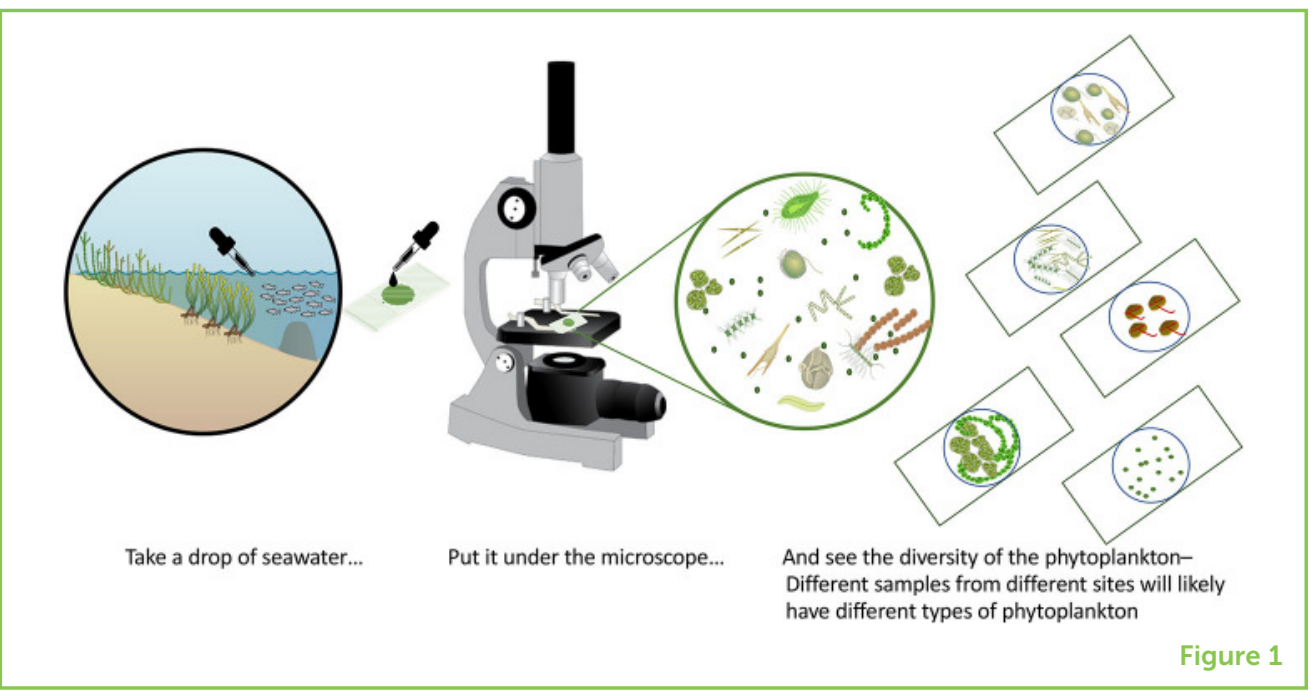

spears to catch their prey and glide like torpedoes! After all, it is the fastest of all the fish. All these organisms are amazing: strong, fast, and ferocious.

However, there is another group of organisms so powerful that the oceans could not function without them-but they are so tiny you have probably never seen them! These are the microscopic plankton. They are called plankton because they just drift with the sea. The smallest plankton can only be seen with a microscope and, even though you will see many different types of plankton with a microscope, some plankton are so small they may look like teeny-tiny dots (Figure 1). What gives these minuscule organisms such power? Why do we even care about something we cannot even see? They are not great swimmers. They do not have strong teeth-or any teeth at all, actually! They are important because they are the food on which all life in the sea depends (Figure 2). Without plankton, there would be no fish, no whales, no sharks, no turtles, and no clams or oysters.

\section{PHYTOPLANKTON ARE THE MOST POWERFUL TYPE OF PLANKTON}

There are many types of plankton. Phytoplankton are the microscopic plant-like organisms, also often called algae or microalgae. Of all the plankton, phytoplankton are the most powerful ocean organisms because they can use sunlight for energy, and grow through the process of photosynthesis. Phytoplankton then become the food for other ocean organisms. The phytoplankton are not only responsible for making food for the oceans, but they are also responsible for almost half of all the oxygen in the world! By performing photosynthesis, they use carbon dioxide from the water and they make oxygen, which most living organisms, including humans, need to breathe. So, thank the phytoplankton the next time you eat seafood or take a breath! 
Figure 2

Food for the fish, sharks, and other ocean organisms begins with the growth of phytoplankton. Phytoplankton may be eaten by zooplankton, which are then eaten by small fish, and so on (Image credits: the symbol library of the University of Maryland Integration and Application Network and open access images.)

\section{ZOOPLANKTON}

Animal-like plankton organisms that eat other plankton organisms-like phytoplankton, bacterioplankton, or mixoplankton.

\section{MIXOPLANKTON}

Plankton that can combine photosynthesis (like a plant) and feeding (like an animal) for their nutrition.

\section{BACTERIOPLANKTON}

Aquatic bacteria that help to decompose detritus and dead organisms and recycle their nutrients.

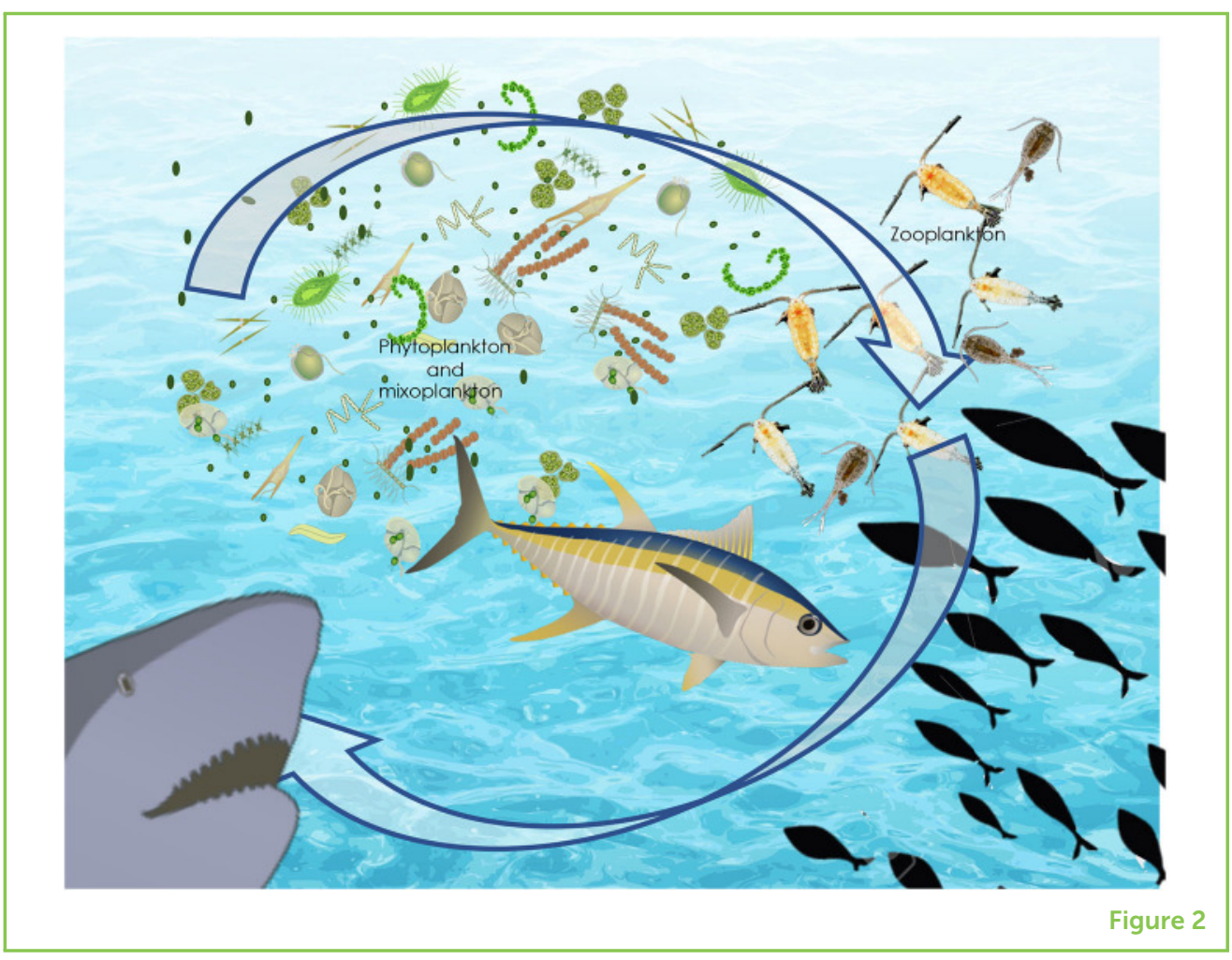

Zooplankton are the tiny animal-like plankton. You can remember their name easily-just think of animals in a zoo! Zooplankton eat the phytoplankton (and some other types of plankton too). They are important in the food chain of the oceans (Figure 2). Zooplankton are eaten by small fish. Like a link in a chain, one organism eats another and then is eaten by another and so on. In reality, though, the chain is more like a spiderweb, as so many different types of organisms eat so many different kinds of things. Zooplankton do not perform the photosynthesis magic of phytoplankton, so while they form important links in the food chain, they do not make oxygen the way phytoplankton do.

Some plankton are a mix of both phytoplankton and zooplankton in one little body! These organisms can perform photosynthesis, but at the same time they can also eat other plankton [1] (Figure 3). These organisms are called mixoplankton because they are a "mix" of plankton types [3]. Mixoplankton do not have mouths, but they can gobble up entire organisms. Some mixoplankton use a sort of straw that they release to suck out the innards of their prey. Some can make their prey explode, leaving a nutritious soup that they can soak up. Some can even eat other organisms that are much bigger than themselves.

There are also bacteria that are plankton, called bacterioplankton. Bacterioplankton do the recycling of the sea-and so they are also extremely important in the oceans. They help to decompose the bodies of other organisms and, in so doing, the important elements 
Figure 3

(a) A mixoplankton cell having a meal of another small phytoplankton cell. (b) Microscope images showing a mixoplankton cell capturing and then ingesting another small cell. (Image credits: (a) the symbol library of the University of Maryland Integration and Application Network and (b) Stoecker et al. [2]; reproduced with permission of Springer-Verlag)

\section{VIROPLANKTON}

(OR

\section{VIRIOPLANKTON)}

Viruses that can infect other types of plankton or other organisms. (a)

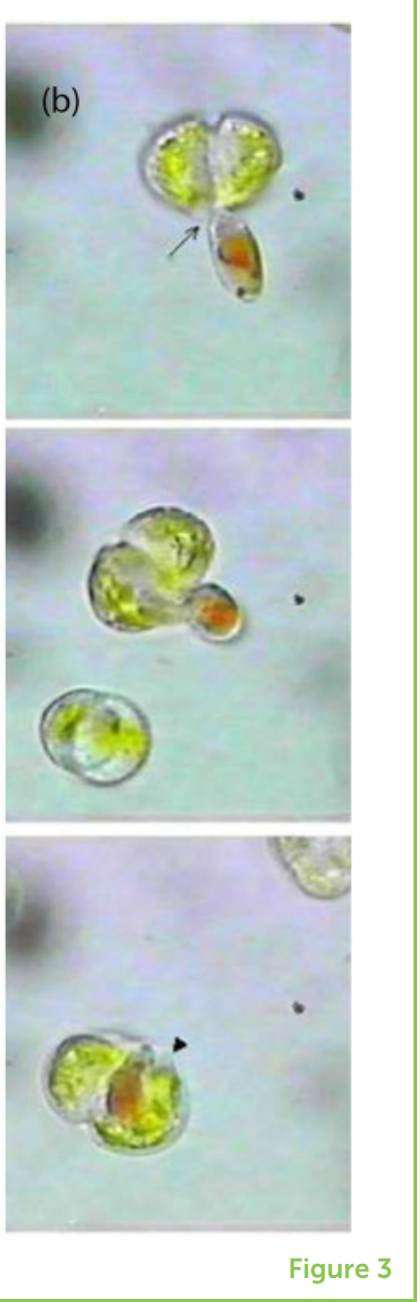

are made available to new organisms. But they cannot perform photosynthesis. Lastly, there are some plankton that are viruses, called viroplankton (or virioplankton), and they can infect other types of plankton, as well as other organisms.

All these different types of plankton interact with each other in complex ways. Together, the plankton make food and oxygen, and they recycle materials for new growth. However, the phytoplankton are the most powerful organisms in the sea, because they are the fuel that makes the whole ecosystem function, laying the foundation for the ocean ecosystem. When mixoplankton act like phytoplankton, carrying out photosynthesis, they too can be considered most powerful. But, like the foundation of a building, if the foundation weakens-or the wrong foundation was used, a building can collapse. Similarly, when there are not enough phytoplankton to make food, or if the wrong types of phytoplankton grow, the food chain of the sea can collapse, turning the ocean into a watery desert wasteland. Food chains-or food webs-of lakes and other freshwaters also depend on phytoplankton for their food. Phytoplankton are powerful in all the waters of the world. 
HARMFUL ALGAL

\section{BLOOM}

Growth of algae (phytoplankton and mixoplankton) that may cause fish kills or seafood contamination through toxins, or that may alter ecosystems in negative ways.

\section{DEAD ZONES}

Regions of oceans and lakes where oxygen levels are too low to support most aquatic life.

\section{NOT ALL PHYTOPLANKTON POWER IS GOOD}

Different types of phytoplankton and mixoplankton are found in waters with different habitats. Some phytoplankton like to live in shallow, nearshore waters, others like to live in more deep or offshore waters. Some like warm waters like those that occur in late summer, some like cooler waters like those that are found in winter or in polar regions. Each species has its favored habitat. Just like the diversity of plants on land, there is a huge diversity of phytoplankton-and some are harmful. There are villains as well as superheroes in this microscopic world!

One way phytoplankton and mixoplankton can be harmful is when too many grow at once. When this occurs it is call a "bloom" (like the blooming of a flower), and this can change the color of the water as they accumulate, sometimes spectacularly. Another term for these events is "harmful algal blooms." Some blooms can turn seawater visibly red, which is the origin of the term "red tide" that is often used to describe such events [4]. Not all algal blooms are red, however-some are green or brown, depending on the pigmentation of the species causing the bloom.

Once these blooms begin to die, their decomposition (by bacteria) uses up oxygen. If too much oxygen is used up, this can result in areas called dead zones. Dead zones are regions of the ocean where there is so little oxygen that most organisms-except some kinds of bacteria-cannot survive. Global occurrences of such dead zones are expanding [5] because more and more blooms are occurring in more and more parts of the oceans.

Another way that phytoplankton and mixoplankton can be harmful is when they make poisons. Just as some land plants can be poisonous, some phytoplankton and mixoplankton can be poisonous too. One mixoplankton species named Karlodinium can release its poisons into the water, destroying the gills of fish, killing them almost immediately. The Karlodinium plankton then eat these bits of fish for their dinner. Another mixoplankton species called Karenia brevis is common off the coast of Florida. It can produce a poisonous compound that can not only kill fish but is even strong enough to kill huge manatees and giant turtles [4]!

People can get sick from these plankton poisons, too. Different types of phytoplankton and mixoplankton make different types of poisons [6]. Sometimes people get rashes on their skin if they swim when these poisonous plankton are in the water. Of greater concern are the poisons that can get into seafood that is then eaten by people. Oysters and mussels eat phytoplankton, but when they eat the toxic types, the poisons can stay in their bodies. When we eat those oysters or mussels, we eat the poisons too. Some poisons may cause an upset stomach or 
diarrhea, but there are stronger phytoplankton poisons that can make us much sicker if we eat seafood contaminated with them. Some of these poisons may make you stop breathing. With too much of this poison people may die. Other poisons from these phytoplankton may cause cancer if people are exposed to them for a long time. Scientists are very interested in understanding what we can do to stop these tiny, toxic organisms from growing out of control and how we can keep people from getting sick.

\section{PHYTOPLANKTON: TINY BUT MIGHTY!}

Phytoplankton are tiny organisms with great power! They are the fuel for the whole ocean ecosystem, and they also have the power to harm or to kill. The next time you see a picture of a shark, a whale, or a huge fish, think about where that animal's food comes from: the mighty phytoplankton. Take a deep breath and thank the phytoplankton for the oxygen they produce. And the next time you see a beach sign warning you not to swim or to eat fish because of toxic or harmful algae, stay away! Respect the power of the phytoplankton and mixoplankton, and keep in mind that lakes, too, can have toxic microalgae. Sadly, we are polluting our lakes and oceans with the nutrients that make these blooms grow from our use of fertilizers on crops that runs off into lakes, rivers, and oceans, so there are many more harmful and toxic phytoplankton and mixoplankton growing today than there were years ago. Climate change is making the situation even worse because many harmful blooms grow very well in warm waters [7]. Let is all do our part to reduce water pollution and slow climate change, so that the good phytoplankton and mixoplankton can continue to grow, feed fish, and give us oxygen. By being good citizens of the planet and reducing pollution, we can all work to keep the poisonous plankton villains in check!

\section{REFERENCES}

1. Glibert, P. M., Mitra, A., Flynn, K., Hansen, P. J., Jeong, H. J., and Stoecker, D. 2019. Plants are not animals and animals are not plants, right? Wrong! Tiny creatures in the sea can be both at once! Front. Young Minds. 7:48. doi: 10.3389/frym.2019.00048

2. Stoecker, D., Tillmann, U., and Granéli, 2006. "Phagotrophy in harmful algae," in Ecology of Harmful Algae, eds E. Granéli, J. Berlin: Turner (Springer). p. 177-87.

3. Flynn K. J., Mitra, A., Anestis, K., Anschütz, A. A., Calbet, A., Duarte Ferreira, G, et al. 2019. Mixotrophic protists and a new paradigm for marine ecology: where does plankton research go now? J. Plankton Res. 41:375-91. doi: $10.1093 /$ plankt/fbz026

4. Glibert, P. M. 2019. Why were the water and beaches in west Florida so gross in summer 2018? Red tides! Front. Young Minds. doi: 10.3389/frym.2019.00010

5. Diaz, R. J., and Rosenberg, R. 2008. Spreading dead zones and consequences for marine ecosystems. Science. 321:926-9. doi: 10.1126/science.1156401 
6. Basti, L., Hégaret, H., Shumway, S. E. 2018. "Harmful algal blooms and shellfish," in Harmful Algal Blooms: A Compendium Desk Reference, eds S. E. Shumway, J. M. Burkholder, and S. L. Morton (John Wiley and Sons Ltd). p. 135-90. doi: 10.1002/9781118994672.ch4

7. Glibert P. M. 2020. Harmful algal at the complex nexus of eutrophication and climate change. Harmful Algae 91:101583. doi: 10.1016/j.hal.2019.03.001

SUBMITTED: 28 August 2020; ACCEPTED: 16 July 2021; PUBLISHED ONLINE: 17 August 2021.

EDITED BY: Emily King, Xiamen University, China

CITATION: Glibert PM (2021) Tiny Phytoplankton: The Most Powerful Organisms of the Oceans! Front. Young Minds 9:600102. doi: 10.3389/frym.2021.600102

CONFLICT OF INTEREST: The authors declare that the research was conducted in the absence of any commercial or financial relationships that could be construed as a potential conflict of interest.

COPYRIGHT @ 2021 Glibert. This is an open-access article distributed under the terms of the Creative Commons Attribution License (CC BY). The use, distribution or reproduction in other forums is permitted, provided the original author(s) and the copyright owner(s) are credited and that the original publication in this journal is cited, in accordance with accepted academic practice. No use, distribution or reproduction is permitted which does not comply with these terms.

\section{YOUNG REVIEWER}

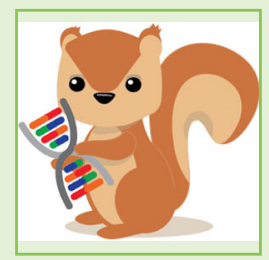

\section{ARIA, AGE: 9}

Aria loves playing with her two guinea pigs and feeding birds and squirrels in her backyard. She gave each squirrel a unique name and lots of peanuts. Aria is always curious about science and she has a lot of questions about nature, animals, and the universe. She also likes singing and drawing in her spare time.

\section{AUTHOR}

\section{PATRICIA M. GLIBERT}

I study algae because I think they are beautiful and important in the world. Phytoplankton blooms are increasingly everywhere, and causing harm in more waters of the world. It used to be difficult to explain what I studied to my non-scientists friends and relatives; now, they read the headlines of water quality issues and algal blooms frequently. I study algae all around the world, from Chesapeake Bay to Florida, from Europe to China! *glibert@umces.edu 